\title{
SEMI-CORE STATES: A NEW CATEGORY FOR RETHINKING THE STRUCTURE OF POWER
}

\author{
Daniel Morales Ruvalcaba'
}

\section{Introduction}

Study the core states and their characteristics, involves scrutinizing the ideas of dependency theorists. However, the literature formulated by the CEPAL and Latin American thinkers clarifies little about this, since they were more concerned with understanding the structural causes of the lag of the periphery, than by studying the core areas.

When speaking of core states, one usually thinks of developed countries. Certainly, the core states are those that have reached the highest standards of development in the world. But the notion of a core is not limited to development, but also denotes advantage in military, cultural, political, environmental, etc. terms. In that sense, certain problems arise: what is specifically understood by core states? Why these states are considered center of the world-system and how did they become so? If the core states outperform the semiperipheral and peripheral states, in what areas do they do so? Does this happen in all areas or only in some areas?

Basically, what distinguishes the core states is the degree of development they achieve. However, the development of national units is conditioned by a time-space continuum that affects their possibilities of creative manipulation: in other words, the development of States is significantly determined by historically constituted structures. And here the value of the notion of core or center, which consist of "the favored areas of the world-economy" (Wallerstein 2003, 492). Thus, the idea translates into a much broader concept that implies wealth and economic development, but also refers to a social and

I Doctor in Social Sciences (Universidad de Guadalajara, Mexico) and Master in Contemporary Studies of Latin America (Universidad Complutense de Madrid, Spain); Research Fellow, School of International Studies, Sun Yat-Sen University. E-mail.. demgdl@hotmail.com 
political advantage.

In this sense, it can be noted that the economic advantage lies in the fact that these nations are, essentially, exporters of goods with high added value and that are immersed in the so-called third industrial revolution, they are headquarters of major stock and financial centers, they possess great number of multinational corporations, have significant capacity to determine global value chains, inflation in their domestic economies is relatively controlled, their international reserves are large and decisive; in social terms they maintain high income and per capita consumption levels, their education and health systems are of high quality, they have managed to guarantee energy supply and ensure considerable resources for scientific research; in terms of politics, they are characterized as mature and consolidated democracies, have efficient bureaucracies and institutions, their armed forces are modern and equipped with relatively sophisticated weapons, there is usually a notorious concentration of global cities in their territories and foreign policy of its national governments is global in scope.

Now, do all the core states occupy identical positions in the hierarchy of world power? Do core states, by the simple fact of being part of the core or center of the system, perform the same functions in international governance? The aim here is to present a new category of States that is located within the center of the world-system: the semi-core States. In the first part, the core States will be studied theoretically; then, with the support of the WPI, semi-core states will be identified empirically and some of the roles that these States play in the international system will be characterized.

\section{National power of the core States}

Perhaps the main theoretical reference for the study of the core, semiperipheral and peripheral areas, is Immanuel Wallerstein. However, when he was questioned about the intellectual paternity of said division, Wallerstein himself replied: "The terms of core and periphery, in the sense in which they are currently used, are in fact from Raúl Prebisch. Prebisch himself may have taken them from some German authors who had written in the I920s and whose works had also been forgotten, but in any case, if there is a father for these two terms, that father is Raúl Prebisch" (Aguirre Rojas 2003, 210). Undoubtedly, the Argentine economist is the main precursor of the center-periphery postulates. But what were the sources that inspired the Argentine economist? It is very difficult to specify ${ }^{2}$ since, according to Joseph Love, Raúl

2 In his study, Jaime Estay finds in Raúl Prebisch "a very clear tendency not to mention the 
Prebisch never specific how he came up with the notions of center and periphery (Love I996, 392). Despite that, in the various studies on Prebischian thought, Werner Sombart 3 , Ernst Wagemann ${ }^{4}$, François Perroux and Mihail Manoilescu have been identified as possible influencers.

However, the preoccupation of Raúl Prebisch was to study the structural causes of the backwardness of the periphery, not the advantages of core economies: the same Raúl Prebisch wrote that "as for the centers, I have to worry about them to the extent necessary to undertake the critique of capitalism" (Prebisch I976, 8). For this reason, configuring the characteristics of the core and the so-called core states is a very difficult and complicated task, since it consists in reconstructing this notion from fragments of ideas -which were secondary- in the texts where the core-periphery model was exposed.

The objective of this section is precisely to outline the features of the core States based on their economic-military, socio-institutional and communicative-cultural power.

\section{Military-economic power of the core States}

To understand the economic-military power of the core states, it is necessary to decompose it into its most elementary elements: economy (production, trade, finance), military apparatus, territory and investment in science and technology.

The main characteristic of the core economies is that they have a pre-

sources of his proposals, neither in the official documents of CEPAL that he elaborated -a question that could be linked to the nature of those documents - nor in the other materials that he wrote throughout his life" (Estay I995, I20).

3 According to Joseph Love, "Prebisch does not remember the knowledge of Sombart's text at the time of his initial use of the terms 'core' and 'periphery' but, even assuming that he was inspired by Sombart, Prebisch would have had more than a striking metaphor, since Sombart only used center and periphery in a few scattered paragraphs" (Love I996, 26).

4 In the opinion of Francisco Zapata, Ernst Wagemann (I884-I956) "can be considered the father of the idea of "periphery" (Zapata 200I, I46), he considers that his ideas had a significant impact on Latin American economic thought. For his part, Joseph Love argues that Raúl Prebisch, quite possibly, had known the work of Ernst Wagemann, who "directed the Institut für Konjunkturforschung in Berlin and became an important apologist for the Grossraumwirtschaft [great economic space] of Hitler in the late I930s. In Struktur und Rhythmus der Weltwirtschaft (I93I), Wagemann used 'central cycle' (zentrische Konjunktur) to designate movements of monetary income within a given country and 'peripheral cycle' (periphere Konjunktur) to designate capital movements in the international arena. In this way Wagemann used a core-periphery scheme in connection with a cyclic movement, but not in the sense that Prebisch shared with Sombart" (Love I996, 392). 
dominantly industrial and homogeneous production structure (that is, almost all sectors are developed) that allows them to create new products, to be at the forefront in production and organization methods, and to discover new sources of energy. Also, they have the wide participation in the national production of industrial activities and services. In an adaptation of the ideas put forward by Raymond Barre (I962), it is possible to describe the productive systems of the core states as those in which: increasing quantities of raw materials and fuel are economized; increase their own production of raw materials and fuels; there is an important production of replacement materials; and, the transformation of the industrial structure is significant.

The central states productively surpass other societies of the world-economy thanks to their technological and scientific advances. The postulates of mercantilism -which bet, broadly speaking, on international economic competition through the increase of national production through the control of resources in domestic and foreign markets- were obsolete before the technological advances of the first industrial revolution, when the economic rivalry moved to the efficiency in the factory production. From this moment, States were forced to develop dynamic competitive advantages through strategies for the advancement of knowledge. Peter Drucker argues so: "The traditional factors of production -land (that is, natural resources), labor and capital- have not disappeared, but have become secondary. They can be obtained easily, as long as have knowledge. And knowledge in this new sense is knowledge as an instrument, as the means of obtaining social and economic results" (Drucker I994, 47). Thanks to the development of capitalism in their societies, the central states found themselves in a position to invest large resources in activities related to research. This allowed them to be at the forefront of the industrial revolutions for their discoveries and scientific-technological innovations. In historical terms, some productive "jumps" for the core areas of the world economy occurred with the first and second industrial revolution, in the seventeenth and nineteenth centuries, respectively. From these revolutions, the economies of the center deployed highly competitive productive structures that allowed them to enhance their international trade.

In his work Das Kapital, Karl Marx postulated that capitalist accumulation is achieved from a dynamic of social transformation characterized by the expropriation of the work of others in a regime where the producer is free owner of their means of production. Once this dynamic of transformation is generalized and deepened, then it adopts a new form, where the capitalist exploiter of several workers is, in turn, expropriated by another, more powerful capitalist. So, "that expropriation is carried out by the play of the immanent laws of capitalist production itself, the centralization of capital. Each capitalist dis- 
places many others. Parallel with this centralization of capital or expropriation of many capitalists by a few, it develops on a growing scale" (Marx I999, 648). As can be seen, the concept of centralization of capital is different from those of accumulation and concentration: even Karl Marx himself clarifies that centralization "should not be confused with accumulation and concentration" (Marx I999, 529). The notion of centralization has thus a special heuristic value for the analysis of the emergence of the core areas in the modern world-economy.

Thus, in Marxist thought the notions of accumulation, concentration and centralization are complementary and very important since they explain the way in which capitalists extend the scale of their operations: the first refers "to the gradual increase of capital through reproduction" (Marx I999, 53I), that is, the investment of the surplus for the generation of new capital; while the second, is understood as the growth of all individual capital from the search for greater productivity. Centralization, on the other hand, consists in "the attraction of some capitals for others" (Marx I999, 530) or in the growth of capital by the union of several capitals. Centralization, on the other hand, has as two powerful levers the concurrency and credit, and can be achieved by altering 2 the distribution of existing capital, through a simple change operated in the quantitative grouping of the parts that make up the social capital" (Marx I999, 530). Besides being a much faster process, centralization causes the concentration of capital and accelerates the effects of accumulation. Finally, the ultimate consequence of centralization is that social wealth tends to agglomerate unlimitedly (Singer I999, IOI, Lianos I984) in a small group of big capitalists, accentuating with it the social disparities. Karl Marx expressed it in the following way: "what happens when certain capitals become centers so absorbing of gravitation for others, [is] that they break their individual cohesion, assimilating then their loose pieces" (Marx I999, 53I).

Banks played a key role in the process of centralization of capital. The origin of banking institutions dates to the first cycle of accumulation of capital, in Genoa around the sixteenth century. At that time, the most prominent banks were: I) the Bank of Amsterdam, founded in I609, served a very large segment of the population (nobility, leaders, monarchs, etc.) and, in practice, operated as a central bank (the first in the world) providing liquidity to the government; 2) the Amsterdam Stock Exchange, created at the beginning of the I7th century by the Dutch East India Company (VOC), was not only the first stock exchange in the world but also served as a market for products from the American colonies, Asian and African coasts.

However, banks (and credit) represented only a lever for the centralization of capital. The other lever is concurrence or competition. Here, transnational corporations (TNCs) play a fundamental role. 
Indeed, the economic power of the core states is closely related to the agency of their TNCs: from the sixteenth to the eighteenth centuries, they invested mainly in the primary sector; from the nineteenth century, they began to operate with greater intensity in activities of the secondary and tertiary sectors; in recent decades, they have developed increasingly complex forms of production and organization. However, the success of TNCs has not been solely and exclusively thanks to the use of new means of production and communication in the context of a contemporary global competition, but also to access to new financial markets, the productive articulation with other companies and the fragmentation of value chains. In this sense, Manuel Castells points out that "multinational corporations are the powerful owners of wealth and technology in the global economy since most networks are structured around them. But, at the same time, decentralized networks are differentiated within them and depend on their members outside in a complex and changing structure of intertwined networks" (Castells 2005a, 220-22I). All this has allowed the reduction of costs of the TNCs in their activities of coordination, logistics and monitoring.

These factors have contributed to position TNCs as fundamental in the functioning of the global economy and are mainly responsible for the development and expansion of global value chains (GVCs). Indeed, the central states and their TNCs are characterized by staying at the forefront of organizational methods, by managing the global production chains and controlling the nodal points that yield the most profits. In this regard, Immanuel Wallerstein finds that "the activities of the most profitable nodes have tended to be geographically concentrated in a few, relatively small, areas in the world-economy, which we can collectively call the core area" (Wallerstein 2008, 88).

However, to increase their economic capacity, the core States need to absorb large amounts of material resources, which in principle they find in their territory. These resources are jealously protected by them. The problem is when resources are exhausted or insufficient: once the impregnability and sovereignty of the national territories has been assured, the central States have gone abroad in search of more resources, an action that has led them to subjugation of other peoples, to the establishment of colonies beyond their borders and the control of new strategic trade routes.

Throughout history, the central states have controlled territories of both natural value and geostrategic relevance: for Ruy Mauro Marini, "the creation of a large modern industry would have been severely hampered if it had not had dependent countries" (Marini I986, 20). In fact, it was the colonization processes and the definition of specific roles for each society in the international division of labor that allowed the core societies to obtain the endowment of natural resources necessary to sustain the growth of their working classes. As 
explained by Osvaldo Sunkel and Pedro Paz, the Industrial Revolution was not a process that occurred in isolated countries, but rather it developed within an economic and world system that linked the industrially advanced countries and regions with economically backward areas. Finally, these asymmetric links contributed "to structurally and institutionally adapt the economies and societies of the peripheral areas to the needs of the process of the Industrial Revolution in the core" (Sunkel and Paz I980, 45). Thus, the concentration of economic power in the central states stimulated their military strengthening.

From its origin, the States had to face an urgent problem: security. The history of international relations has shown that economic production and military power are needed and nourish each other. With his research, Paul Kennedy demonstrated that there is "a very obvious connection between the economic rise and fall of a great power and its growth and decline as a major military power" (Kennedy 2007, 20). Although they do not necessarily occur in parallel, the centralization of wealth contributes to the increase of military power.

One of the characteristics of the Wars of Religion of the sixteenth century, was the systematic use of mercenaries who, together with regular armies and the rapid improvement of weapons, created a climate of insecurity widespread in Europe. In this context, the State was increasingly obliged to guarantee the conditions for the realization of economic activity and, for this, the State needed to develop its military capabilities.

In this way, modern state increased its economic-military power through reciprocal collaboration between monarchs and wealthy. In this regard, Henry Pirenne writes that between governments and capitalists a true solidarity of interests was established: "on the one hand, without the constant intervention of the financiers, the princes could not cover their expenses neither public nor private; but, on the other hand, the great merchants, the bankers, the shipowners, count on the princes to protect them against the abuses of municipal particularism, to repress the urban insurrections, to ensure the circulation of their money and their merchandise" (Pirenne 2003, 156). Thus, in the process of shaping the modern state, the association between wealth and military power played a fundamental role.

Currently, central states would be characterized by having significant capacities for national security. An indicator that reflects the military power is the expenditure destined for this item. However, the central states -unlike some semiperipherals and peripherals that also designate large sums of money for their defense- can make the most efficient use of military spending by investing in research and technology for war. Thus, the armed forces of the central states would be characterized as qualitatively more advanced in their arsenals and war tactics. 


\section{Socio-institutional power of the central States}

Historically, the centers have been constituted as the most productive and competitive areas in the world. This is verifiable not only at the national level, but also in terms of the gross national product per capita, that is, in the set of goods and services produced by a national society, including nationals working abroad.

The core states are economically competitive because they have developed a productive structure that is efficiently linked and capable of guaranteeing the conditions for economic competition at the national level, but they have also generated an internal market and have been able to acquire specialized human resources. In other words, the competitiveness of the central states has not only been determined by productive efficiency and the conditions for economic competition, but also by the quantity and quality of their population bases. In this regard, Pablo Valdés and Juan Salazar explain that "a large population generally means life, activity, activity, progress and international power" (Valdés and Salazar I987, 24). In that sense, one of the demographic characteristics of the central states is that they have the necessary population bases for the location of economic and military activities.

The main difference of the central societies with respect to the peripheral and semiperipheral ones, is the level of relative welfare that they enjoy. And it is that, the origin of the high productivity of the central States, is intrinsically related to their educated populations, well fed, healthy and, therefore, more qualified.

Due to its high productivity at a general and individual level, the central States managed to place themselves at the forefront of capitalism, which allowed them to consolidate highly dynamic and attractive national markets; but, at the same time, centralize wealth from its expansion to other territories. Thanks to this, the inhabitants of the central societies gradually raised their income and consumption levels. Then, societies with high consumption patterns advanced towards the building of modern governmental apparatuses that contributed not only to maintain the levels of well-being already reached, but especially to deepen the standards and quantity of citizens benefited. In fact, problems in the welfare or progress of a national society, immediately refer to the examination of the policies implemented by your government.

In this perspective, Daron Acemoglu and James Robinson argue that it is the political institutions that determine the economic development of a State. For them, "each society works with a series of political and economic rules cre- 
ated and imposed by the State and citizens collectively. Economic institutions shape economic incentives [... but] it is the political process that determines under what economic institutions will be lived and the political institutions that determine how this process works" (Acemoglu and Robinson 2012, 59-60). To paraphrase the economists referred to here, it is possible to point out that the central states advanced in the development of inclusive political institutions -sufficiently centralized and pluralist- that, in the end, contributed to the establishment of inclusive economic institutions, which are characterized by fostering and enabling "the participation of most people in economic activities that make better use of their talent and skills and allow each individual to better choose what they want" (Acemoglu and Robinson 20I2, 96). In this way, the prosperity of a country is closely linked to the quality of its government and its institutions.

Now, the welfare of a national society occurs through "inclusive" state intervention in three areas of human endeavor: health, education and research.

Although the healthiness of a society can be strongly conditioned by climatic and cultural factors, it is up to the State to design strategies aimed at: I) protect public health from risks and serious damages, 2) promote healthy hygiene habits or lifestyles among society that contribute to eradicating or prevent diseases, and 3) develop medicines and clinical infrastructure that will help restore health in the most affected individuals. The core States have historically distinguished themselves by having highly efficient public health systems, that is, systems that have functioned effectively (although always in terms relative to each era) in the protection, promotion and restoration of health among their citizens. Proof of this is that, their populations show reduced infant mortality and malnutrition levels, low rates of maternal morbidity and, in general, high standards of life expectancy at birth.

Another fundamental factor for the protection of public health has been the management and use of natural resources. The pollution of air, water, soil, food, etc., has historically been the trigger for epidemics and pests. It is impossible to say that the core States were exempt from corrupting their environment and polluting their resources; in fact, the core states also crossed the so-called "environmental curves of Kuznets" (Gudynas 2004, Dauvergne 20II), but at a time that was historically viable and sustainable.

Closely related to the field of public health, is education. The main objective of public education is and has been to ensure its accessibility to the entire population. In this work, without doubt, the national government plays a fundamental role, since it is the main responsible for the planning, review and implementation of the curricula (for all educational levels).

It should be emphasized that what is most relevant in education is not 
only its contribution to the development of skills for writing, reading comprehension and mathematical calculation, competences that are essential for the functioning of any modern society; but what is most extraordinary is the effect it has as a catalyst and driver of creative talents among individuals, which contribute to invigorate development and, ultimately, general well-being: in the words of Daron Acemoglu and James Robinson, it is education "what generates the scientific knowledge on which progress is built and what allows the adaptation and adoption of these technologies in various business lines" (Acemoglu and Robinson 2012, IOO).

In this sense, an important characteristic that distinguishes the central States in this area is that they have highly competitive educational systems, which operate based on a modern physical infrastructure and trained human resources. This is possible thanks to the sustained and prolonged investment -both in basic, technical and professional education- that contributed to reducing illiteracy and raising average schooling of individuals. In this way, high rates of education in young people and adults led these societies to deepen their knowledge through educational institutions of higher or advanced education: universities. The core States also stand out for their accumulation of universities, research centers, laboratories and think tanks with enormous prestige worldwide.

Finally, such active and productive societies necessarily involve large demands for energy. No nation, however far advanced in its process of industrialization, has managed to be completely self-sufficient in energy terms. However, because they are at the forefront of productive development, the core States have the possibility of relatively lacking their own fuels, since they import them from abroad. In addition, throughout history, have had technological infrastructure to innovate in strong energy and economize increasing amounts of fuel.

\section{Communicative-cultural power of the central States}

As the central countries advance in economic development, the values and lifestyles in their societies are being modified, establishing fashions and trends in cultural, intellectual and ideological terms.

The attractiveness of the central states over the rest of the most backward national societies was theorized under the name of "demonstration effect" (Barre I962, 4I). For Fernando Henrique Cardoso and Enzo Faletto, the demonstration effect assumes -in the economic sphere- that modernization "is situated through consumption and that, consequently, it introduces an element of alteration in the productive system that can cause a deviation from the 
'stages' of industrialization characteristic of the advanced countries" (Cardoso and Faletto I999, I6). This means that the economic advantage attained by the central states influences the laggards, inducing them to imitate or emulate the same stages of industrialization followed by them. However, the demonstration effect is not only limited to the economic, but also "assumes that the same factors that favor this process put pressure on the underdeveloped countries to alter other aspects of human behavior - in the political field and in the social field - before the complete differentiation of the productive system is verified" (Cardoso and Faletto I999, I6). Therefore, the influence that the central states can exert on the peripheral and semiperipheral states is not limited to the economic level, but goes beyond the socio-cultural, ideological and dogmatic. This power of attraction of some States has been also theorized with the name of soft power (Nye 2004a, Nye 2004b). In terms of Immanuel Wallerstein, the ideological-cultural battle is waged in the field of geoculture (Wallerstein, Geopolítica y geocultura 2007).

The question, then, is how do the central states exercise their demonstration effects, increase their soft power or symbolic power and overcome geo-culturally? There are some aspects that escape the state apparatus, since they are rooted in popular culture or in the historical development of these; but, there are other means that depend directly on governments and on the management of public resources.

Government spending, that is, the total expenditure made by a national government, aims to repair the failures of the national market and boost public consumption through the social redistribution of wealth. As already explained in previous sections, some strategic areas in which government spending intervenes are defense, education, health, energy and research and development. Certainly, the final destination of public spending is the national society, but its incidence goes far beyond the borders: States with high government spending have the possibility not only to influence some key sectors for development, but also can intervene in others -such as tourism, diplomacy, communications, creativity and technology- which directly contribute to transmitting abroad images or specific projections of the society-national. A feature of the central states is that historically they have had government expenditures that have allowed them to exert demonstration effects, strengthen their soft power and influence geoculturally others.

However, public spending also allows States to maintain representations outside their territory -either before other States or against international organization- through their diplomatic missions: lower budget, restricts the international presence of a State; higher public spending, allows a State to establish diplomatic relations with more States and participate in more international 
organizations. Moreover, for several decades, rich countries have allocated special amounts of their budget to help poorer countries. These disbursements of donations or credits have been denominated as assistance or official aid for development (ODA). The scope of ODA is extremely significant since donors can use it as a tool of influence or pressure for recipients to assume certain positions in international forums or implement certain internal policies. Of course, core States have not only dispensed with ODA, but historically they have been the main donors and providers of aid to the most backward economies.

Another means by which a State demonstrates its cultural attraction is international tourism. Tourism is a very complex activity, involving a wide range of activities, sectors, products and services. For this reason, is that tourism has been seen, for several decades, as "an essential activity of the life of nations, for its direct consequences for the social, cultural, educational and economic sectors of national societies and their relationships international around the world" (World Tourism Organization I980). Although some of the most relevant actors for tourism are tourism companies (micro, small, medium and large) and civil society (non-governmental organizations, educational institutions, business groups, etc.), without a doubt the government is the principal responsible not only to regulate tourism, but especially to provide the necessary infrastructure for the reception, mobility and comfort of tourists. In that sense, tourism activity and infrastructure depend to a large extent on government expenditures.

The core States have distinguished themselves by having works, shows and sites of great tourist interest; but, more than that, they have the resources to promote themselves internationally. In addition, they have developed sufficient infrastructure to receive and guarantee the safety of thousands of visitors. In this way, tourism in the central States has a double effect: on the one hand, it allows international currencies to be captured directly and efficiently; on the other hand, it strengthens an image of society among tourists and communicates stereotypes of the nation in their countries of origin.

Closely related to tourism are the media and telecommunications. This area would be formed by two major items: devices for communication and message content.

Historically it can be seen that the prevalence of minimum levels of prosperity has been a necessary condition in the invention of new media for communication: productive activities with high added value related to industrial design and innovation flourish especially in societies that enjoy high levels of educational, economic prosperity and relative social peace. For these reasons, the core states are ideal scenarios for inventiveness and creativity. However, the benefit of technological development for the central economies lies both in the 
usufruct resulting from its commercialization and mass sale, and in the registration of exclusive rights over new products or technologies. The core States are pioneers in the research and development of ICTs, but also in the manufacture and export of high technology products, which must do especially with the computer and electronics industries. That regarding devices for communication.

Regarding the content of the message, the media represent an instrument of power, since it is through them that States promote images, broadcast speeches, disseminate propaganda or manipulate informative messages with the objective of strengthening the interests of specific groups. That is why the cultural, informative and creative industries are an indispensable factor in the legitimation of the national power of any State.

In these areas, the central States have had sufficient resources to develop innovative means of communication, as well as to provide them with content. This work is done in partnership with the TNCs and civil society, being important not only celebrities, entertainers and entrepreneurs, but also universities, think tanks and mass media, to mention the most outstanding.

In addition to simple entertainment, the pattern outlined by the central States also goes beyond what is defined as science, that is, the field of science. Indian thinker Chakravorty Spivak argues that "meaning / knowledge intersects with power" (Spivak 20I0, 2I6). In terms of power relations, it is possible to verify that, over the centuries, the central states imposed a certain episteme on the less developed states of the world system. This work continues today through the production and reproduction of knowledge through articles published in books, fascicles and journals considered scientific.

Finally, being economically prosperous zones, the core States exert great force of attraction on the national-societies located in the semi-periphery and the periphery of the system. This, in the free market game is translated, as Raymond Barre argues, in that "center of expansion, industrial or commercial, is a center of attraction of men, goods and services, capital, intellectual and social life" (Barre I962, 46). In this way, one feature of the central societies is the number of migrants that inhabit their territories, a fact that contributes to their cosmopolitanism. And, the plurality of social groups with diverse ethnic origins has an impact on inter-civilizational dialogue, brings new values and ideas and culturally enriches society

\section{Categories of core States in the international structure}

In the seventeenth century, the capitalist world-economy was already installed and centered on Europe. More specifically, Fernand Braudel considered 
-at that moment- "the core of the world is the minuscule Netherlands" (Braudel I986, 99). But is Amsterdam and the United Provinces exclusively the core of the modern world-economy or is it possible to mention some surrounding regions? Moreover, when the Netherlands lose their hegemony in favor of Great Britain, what geographical area could be considered the core?

In making an empirical description of the States belonging to the center, Werner Sombart wrote: "the capitalist center was constituted by England during the first half of the nineteenth century; later [it was], during most of the epoch of the apogee of capitalism, 'Western Europe', that is, in addition to England a space limited by a line that, starting from the South of Sweden, followed by Antwerp, Amiens, Paris, Mülhausen, Milan, Voralberg, Lower Austria, Moravia, Lodz and Berlin, to end up in Sweden again; finally during the last generation the eastern region of the United States of America has become part of this center" (Sombart I946, IO-II). Thus, if it were to leave southern Sweden (for example, in Stockholm), the perimeter described by Werner Sombart would include -in addition to Great Britain- the territories of what is currently the Netherlands, Belgium, Luxembourg, France, Switzerland, Italy, Austria, Czech Republic, Poland, Germany and Denmark. Indeed, all these countries have historically distinguished themselves by their centrality in the world-economy. But, in the current context, what other could be classified as core States?

Peter Taylor and Colin Flint, meanwhile, argued that it is common to use the term "core" to refer to the rich countries of North America, Western Europe and Japan" (Taylor and Flint 2002, 2I). But, empirically, what States of North America and Western Europe are they talking about? Are these regions the only ones with central states?

Based on the ideas presented in the previous section, the core states are those that stand out not necessarily because they have the highest economic-military power, but because they hold important levels of socio-institutional power -stable in the high levels of welfare- and for having significant levels of communicative-cultural power for its geocultural projection in the system. At present, 29 can be mentioned as core states: Germany, Australia, Austria, Belgium, Canada, South Korea, Denmark, Slovakia, Slovenia, Spain, United States, Finland, France, Greece, Netherlands, Hungary, Italy, Ireland, Israel, Japan, Luxembourg, Norway, New Zealand, Portugal, United Kingdom, Czech Republic, Singapore, Sweden, Switzerland. Evidently, there are hierarchical and functional differentiations among the group of core states mentioned here. To distinguish them more clearly, the core states will be classified and analyzed here based on three categories: great powers, middle powers and semi-core states. 


\section{Great powers and middle powers}

The great powers are the states that, throughout history, have shown the greatest endowment of material, semi-material and immaterial capacities. Thanks to this, as well as to its formidable positioning in the world economy, the great powers have enough power to act autonomously, impose their policies on other countries and lead the global economy. In this sense, the great powers are the main actors in international governance: in other words, the great powers are directives or constitute the directory in international governance. They are 7: United States, Germany, Japan, France, United Kingdom, Italy and Canada.

In hierarchical terms, after the great powers, there are the middle powers: equally core States, with important levels of development and social welfare, but with less economic-military power and communicative-cultural power. They are Iı: Spain, Australia, South Korea, Netherlands, Sweden, Belgium, Switzerland, Austria, Israel, Norway and Denmark.

Due to its important position in the international structure, the middle powers are outstanding actors for international governance. However, unlike the great powers that lead and direct, the middle powers have relatively less economic-military power, which partially restricts their performance and forces them to adopt "secondary" roles: the great powers lead while the middle powers second. Hence, the middle powers can be qualified as contributors (Rocha and Morales 20I0) since, in general terms, they cooperate widely with the great powers in different spaces, forums and organizations.

\section{Semi-core states: the less favored part of the center of world-sys- tem}

Showing welfare levels almost as high as those of the middle powers, there is a group of developed states that exhibits certain specificities. Following the IMF rankings, most of this group of countries enjoys the recognition of advanced economies (International Monetary Fund 20I3, I2I) although, obviously, it is not about the great powers or the middle powers. These states are II: Czech Republic, Finland, Greece, Hungary, Ireland, Luxembourg, New Zealand, Portugal, Singapore, Slovakia and Slovenia.

According to the Semi-Material Capacities Index (SMCI) data (Rocha and Morales 20I8), it is possible to corroborate that, immediately after the seven great powers and the eleven middle powers, the semi-core states stand out for their high levels of development and prosperity: besides to being able to 
solve efficient education and health systems, for the past five years the small societies of these countries (since they number between II million and 500 thousand inhabitants) have maintained a GNP per capita of more than US \$ I6,000 (with the exception of Hungary) and an energy consumption greater than 3,000 kilowatts per capita. In Graph I. Semi-Material Capacities Index of Semi-core states, I975-20I5, it is possible to appreciate that the semi-material capacities, source of the socio-institutional power of the States, have remained high and relatively unchanged in the last three decades, except for the notorious cases of Singapore (before i984), Portugal (before the 9o's), Hungary and the Slovak Republic (in the years before the 2Ist century).

\section{Graph 1. Semi-Material Capacities Index of Semi-core states, 1975- 2015}

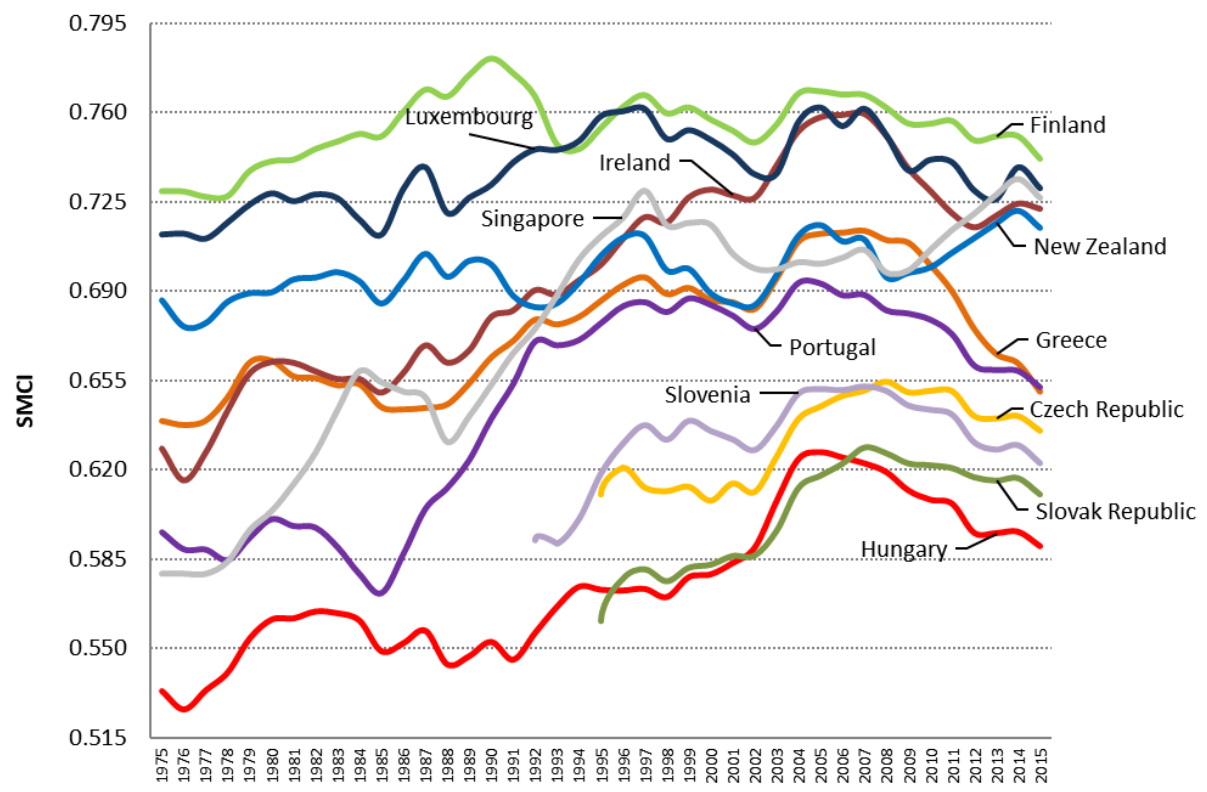

\section{Own elaboration}

A characteristic feature of this group of States is their notorious lack of economic-military power. As shown by the Material Capacities Index (MCI) data (Rocha and Morales 20I8), these countries manifest a lack of material capabilities for the exercise of force in international politics: the GNP of none of them (except for Greece between 2008 and 20I0) has exceeded one third of a trillion dollars, its territorial areas are relatively small (being Finland the most 
extensive), its population growth rates are below $2 \%$, its military expenditures are short (except for Singapore and Greece, the rest has never designated more than US \$ 5 billion in this area), amounts for research and development are relatively small (they have never exceeded US \$ Io million) and their international reserves and trade with the world are relatively minor. Thus, their material capacities -sources of economic-military power- could be qualified simply as median.

In addition, a phenomenon that can be seen in the Graph 2. Material Capacities Index of Semi-core states, I975-2015 and that it is important to highlight, is that all these countries are declining relatively and at different speeds. This suggests that these countries are experiencing a gradual reduction in terms of their strength.

\section{Graph 2. Material Capacities Index of Semi-core states, 1975-2015}

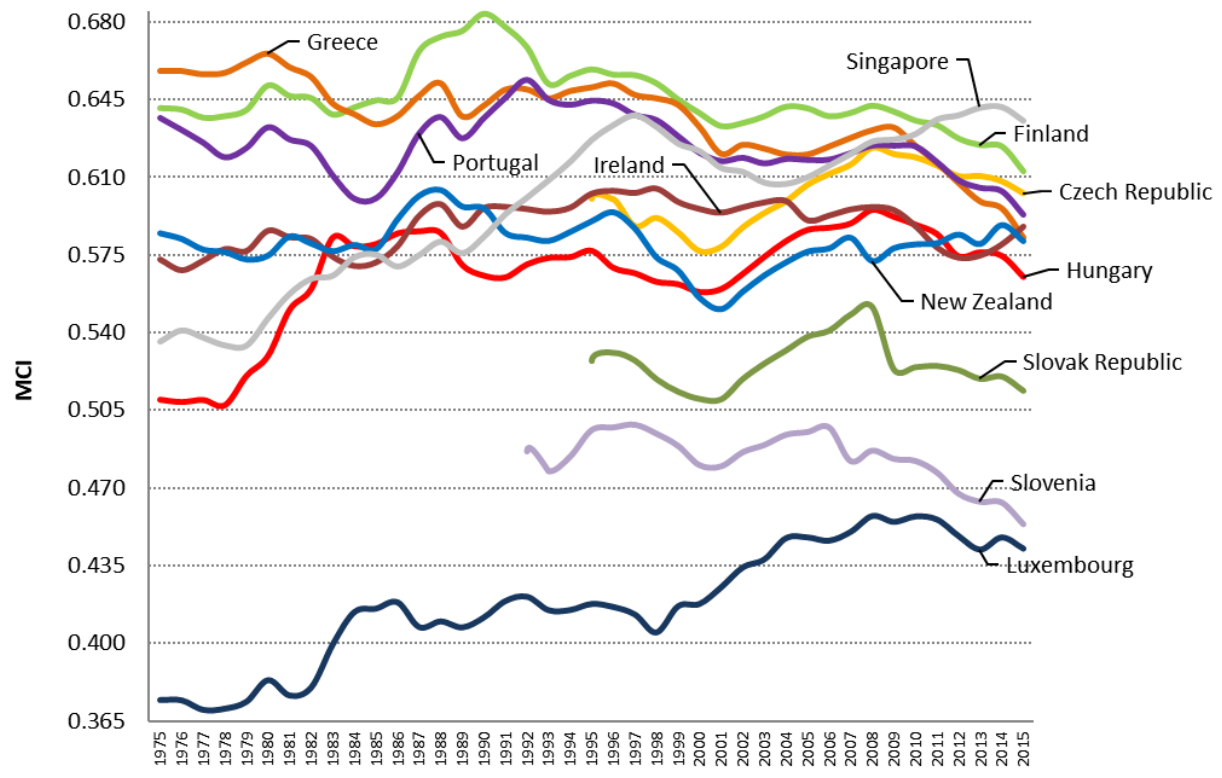

\section{Own elaboration.}

As is seen with the economic-military power, the communicative-cultural power of this group of States is also medium as corroborate the Immaterial Capacities Index (IMCI) data (Rocha and Morales 20I8): all the States identified here as Semi-core are ODA donors and their cultural attractiveness is relevant (it is enough to observe the amounts collected for international tour- 
ism and the number of migrants living in its territory); however, at the same time, their public spending and the academic production of their universities are significantly lower than what the great powers and the middle powers. An important deficiency lies in the less amplitude and reduced influence of their media, which reduces their communicative capacity and global influence.

From the curves that are presented in Graph 3. Immaterial Capacities Index of Semi-core states, I975-20I5, it is possible to highlight two situations: I) despite its limitations, the communicative-cultural power of these countries has been increasing slowly in recent decades; 2) the States that possess the greatest immaterial capacities of the group presented here are Greece and Portugal, countries that, thanks to their glorious past, are still projected as cultural and tourist benchmarks for many nations.

\section{Graph 3. Immaterial Capacities Index of Semi-core states, 1975- 2015}

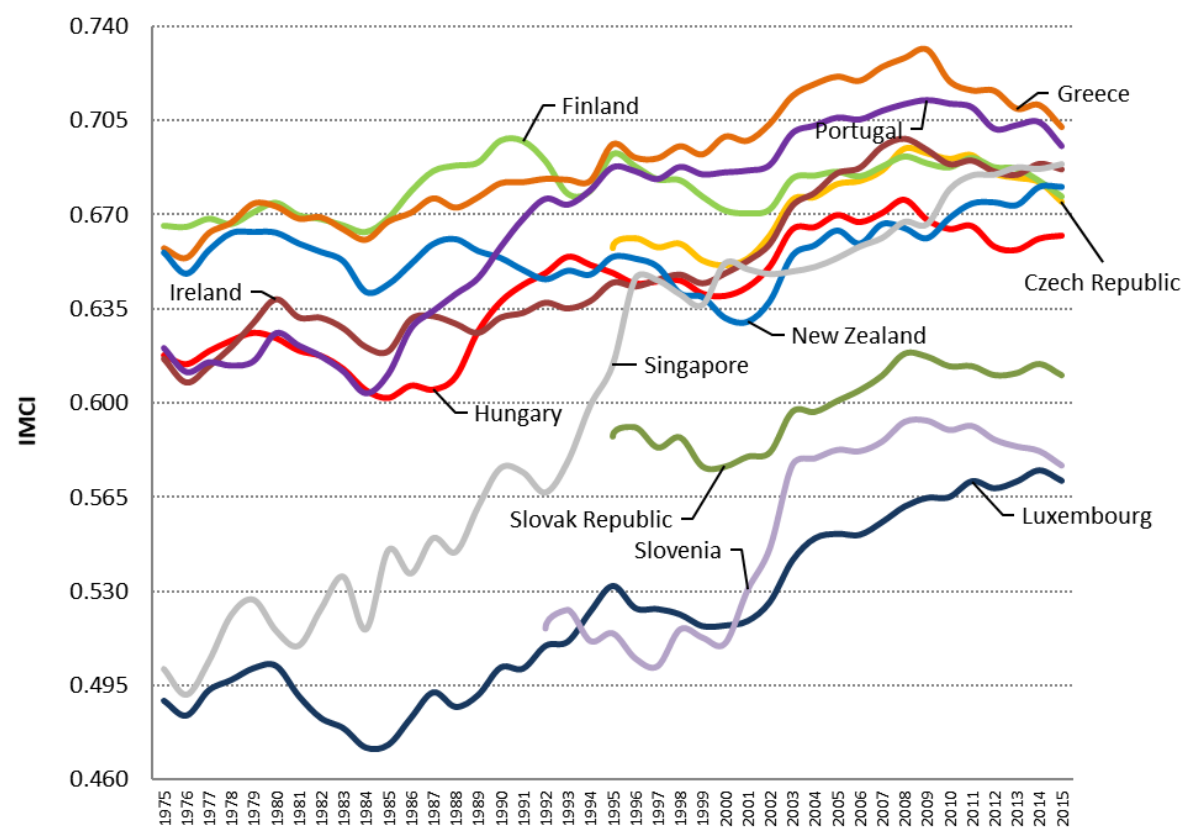

\section{Own elaboration.}

Unlike the great powers and the middle powers, which have enjoyed a notoriously central position for several centuries, the States referred to here, or have recently emerged from the semiperiphery to be incorporated into the cen- 
ter of the system thanks to their geographical proximity to the central powers (in a kind of "drag effect" that is demonstrated by the modernization processes that took place, for example, with the Czech Republic, Slovakia and Slovenia at the end of the Cold War) or were, centuries ago, medium powers that could not maintain their structural positioning and declined (for example, Greece and Portugal). Thus, the position in which these countries are located is the most marginal of the center: the less favored part of the center or semi-core. In addition, these countries historically have depended on their link with the central powers and their expansion / contraction dynamics to stay at the core. For this reason, these countries will be referred to as semi-core states, due to their tertiary position in the center of world-economy, that is, after the main core formed by the great powers and the secondary core composed by the middle powers.

In summary, the World Power Index (WPI) -which shows the national power making a compilation of the material, semi-material and immaterial capacities- of semi-core states can be expressed in the following form (see Annex): MCI medium || SMCI high || IMCI medium. In empirical terms, the semi-core states are: Singapore, Finland, Ireland, Greece, Portugal, New Zealand, Czech Republic, Hungary, Slovakia, Luxembourg and Slovenia.

The notorious lack of material and immaterial capacities shown by the semi-central states, leads them to a significantly more modest structural position in the interrelations of power and in the whole of the international hierarchy. In fact, although they are developed states, they have never received the qualification of "powers", with the notorious exception of Portugal and Greece during their glory years many centuries ago. At present it is not possible to grant them this qualification and it will be very difficult for them to achieve it in the years to come, since -as can be seen in the Graph 4 (next page). World Power Index for Semi-core states, I975-2015- its situation is not one of structural ascent, but of stagnation and, even, regression. 


\section{Graph 4. World Power Index for Semi-core states, 1975-2015}

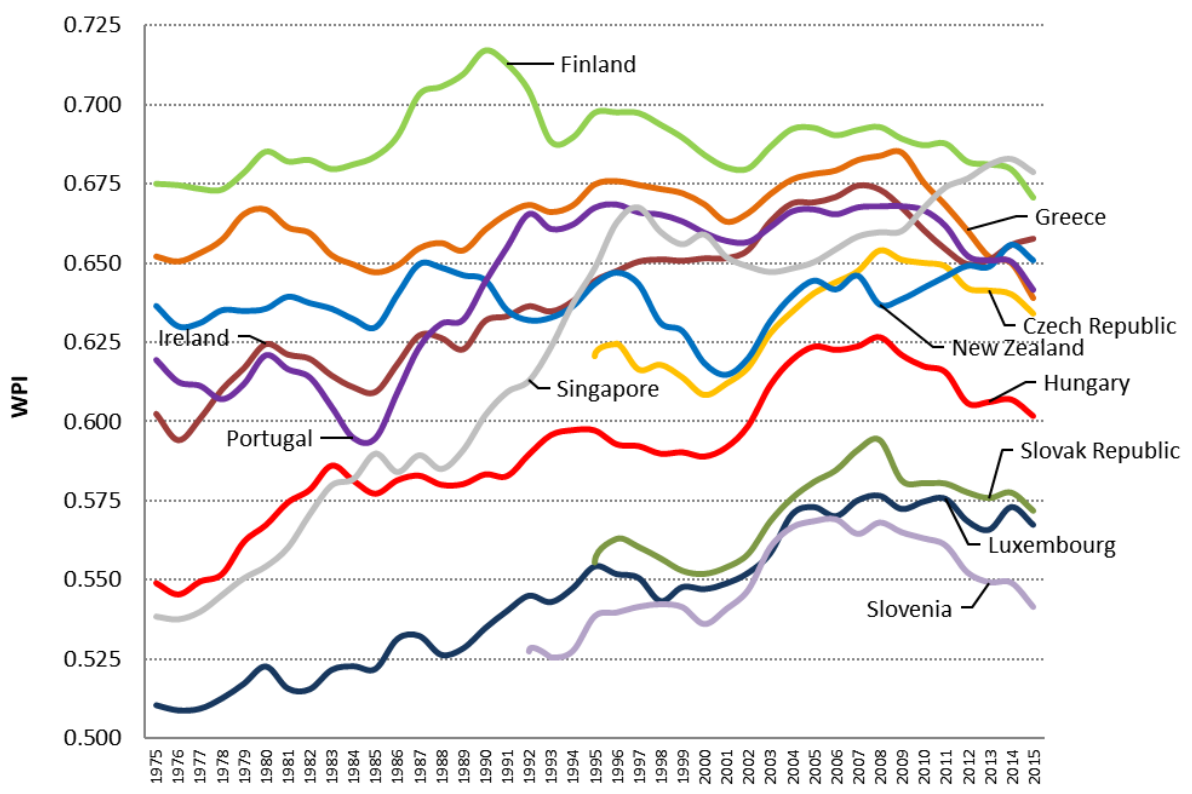

\section{Own elaboration.}

Despite their relative marginality, the semi-core states play specific roles in the functioning and governance of the world-system. While the semiperipheries serve as zones for buffering resistance from the periphery (outer belt), semi-core states act as a last instance of distension of pressures from the semiperiphery (inner belt). Hence, historically, many of the semi-central states are characterized as convulsive and unstable (e.g., Czech Republic, Slovakia or Slovenia). From the geopolitical point of view, the semi-central zones have served as the "natural frontiers" of modernity (e.g., Greece in Europe, New Zealand in Oceania) and have led to the creation of "Buffer States" (e.g., Finland or Estonia) ex officio the interests of the central power.

\section{Final consideration}

This article was aimed, at first, at the characterization of the central States based on their economic-military, socio-institutional and ideological-cultural power; and, in a second moment, to the identification of a new category of non-powerful central states: semi-core states.

Although they are relatively marginal because of their significantly low- 
er material and immaterial capacities, the great powers and the middle powers need semi-core states to maintain stability at the center of the world-system and international governance. For this reason, since a few decades ago, these states have been incorporated into key international organizations, such as the OECD (all have membership, except Singapore), NATO (except for Finland, Ireland, New Zealand and Singapore), the Space European Economic and OSCE (in these, because of their geographical location, New Zealand and Singapore do not participate). Due to the reasons explained in this article, it is argued that the semi-central states -more than coadjutants- are subsidiary to the interests, guidelines and actions of the great powers and the middle powers. 


\section{ANNEX}

\begin{tabular}{|c|c|c|c|c|c|c|c|c|c|c|c|}
\hline \multicolumn{12}{|c|}{ World Power Index for Semi-core states, 1975-2015 } \\
\hline WPI & Czech Rep. & Finland & Greece & Hungary & Ireland & Luxemb. & N. Zealand & Portugal & Singapore & Slovakia & Slovenia \\
\hline 1975 & - & 0.675 & 0.652 & 0.549 & 0.602 & 0.510 & 0.637 & 0.619 & 0.538 & - & \\
\hline 1976 & - & 0.674 & 0.651 & 0.546 & 0.594 & 0.509 & 0.630 & 0.613 & 0.538 & - & - \\
\hline 1977 & - & 0.673 & 0.653 & 0.550 & 0.601 & 0.509 & 0.631 & 0.611 & 0.540 & - & - \\
\hline 1978 & - & 0.673 & 0.658 & 0.552 & 0.610 & 0.513 & 0.635 & 0.607 & 0.545 & - & - \\
\hline 1979 & - & 0.678 & 0.666 & 0.562 & 0.617 & 0.517 & 0.635 & 0.612 & 0.551 & - & - \\
\hline 1980 & - & 0.685 & 0.667 & 0.567 & 0.624 & 0.523 & 0.636 & 0.621 & 0.554 & - & - \\
\hline 1981 & - & 0.682 & 0.661 & 0.574 & 0.621 & 0.516 & 0.639 & 0.617 & 0.560 & - & - \\
\hline 1982 & - & 0.682 & 0.660 & 0.578 & 0.620 & 0.515 & 0.637 & 0.614 & 0.571 & - & - \\
\hline 1983 & - & 0.680 & 0.653 & 0.586 & 0.615 & 0.522 & 0.636 & 0.605 & 0.580 & - & - \\
\hline 1984 & - & 0.681 & 0.650 & 0.581 & 0.611 & 0.523 & 0.632 & 0.595 & 0.582 & - & - \\
\hline 1985 & - & 0.684 & 0.647 & 0.577 & 0.609 & 0.522 & 0.630 & 0.595 & 0.590 & - & - \\
\hline 1986 & - & 0.690 & 0.649 & 0.581 & 0.618 & 0.531 & 0.640 & 0.609 & 0.584 & - & - \\
\hline 1987 & - & 0.703 & 0.655 & 0.583 & 0.627 & 0.532 & 0.650 & 0.624 & 0.589 & - & - \\
\hline 1988 & - & 0.706 & 0.657 & 0.580 & 0.626 & 0.526 & 0.649 & 0.631 & 0.585 & - & - \\
\hline 1989 & - & 0.710 & 0.654 & 0.580 & 0.623 & 0.528 & 0.646 & 0.632 & 0.591 & - & - \\
\hline 1990 & - & 0.717 & 0.661 & 0.583 & 0.632 & 0.535 & 0.645 & 0.644 & 0.602 & - & - \\
\hline 1991 & - & 0.713 & 0.666 & 0.583 & 0.633 & 0.540 & 0.635 & 0.655 & 0.609 & - & - \\
\hline 1992 & - & 0.704 & 0.669 & 0.590 & 0.636 & 0.545 & 0.632 & 0.665 & 0.613 & - & 0.527 \\
\hline 1993 & - & 0.688 & 0.666 & 0.596 & 0.635 & 0.543 & 0.633 & 0.661 & 0.624 & - & 0.525 \\
\hline 1994 & - & 0.690 & 0.668 & 0.597 & 0.638 & 0.547 & 0.636 & 0.662 & 0.637 & - & 0.527 \\
\hline 1995 & 0.620 & 0.697 & 0.675 & 0.597 & 0.644 & 0.554 & 0.644 & 0.667 & 0.648 & 0.555 & 0.538 \\
\hline 1996 & 0.625 & 0.697 & 0.676 & 0.593 & 0.648 & 0.552 & 0.647 & 0.668 & 0.663 & 0.563 & 0.540 \\
\hline 1997 & 0.616 & 0.697 & 0.675 & 0.592 & 0.650 & 0.551 & 0.643 & 0.666 & 0.668 & 0.560 & 0.541 \\
\hline 1998 & 0.618 & 0.694 & 0.674 & 0.590 & 0.651 & 0.543 & 0.631 & 0.665 & 0.660 & 0.557 & 0.542 \\
\hline 1999 & 0.614 & 0.690 & 0.672 & 0.590 & 0.651 & 0.548 & 0.629 & 0.663 & 0.656 & 0.553 & 0.541 \\
\hline 2000 & 0.608 & 0.684 & 0.669 & 0.589 & 0.652 & 0.547 & 0.618 & 0.659 & 0.659 & 0.552 & 0.536 \\
\hline 2001 & 0.612 & 0.680 & 0.663 & 0.592 & 0.652 & 0.549 & 0.615 & 0.657 & 0.652 & 0.554 & 0.541 \\
\hline 2002 & 0.617 & 0.680 & 0.666 & 0.599 & 0.654 & 0.552 & 0.620 & 0.657 & 0.649 & 0.558 & 0.547 \\
\hline 2003 & 0.628 & 0.687 & 0.672 & 0.611 & 0.663 & 0.558 & 0.632 & 0.661 & 0.647 & 0.568 & 0.560 \\
\hline 2004 & 0.635 & 0.692 & 0.677 & 0.619 & 0.669 & 0.571 & 0.640 & 0.666 & 0.648 & 0.576 & 0.566 \\
\hline 2005 & 0.640 & 0.693 & 0.678 & 0.624 & 0.669 & 0.573 & 0.645 & 0.667 & 0.650 & 0.581 & 0.568 \\
\hline 2006 & 0.644 & 0.690 & 0.679 & 0.623 & 0.671 & 0.570 & 0.642 & 0.665 & 0.654 & 0.585 & 0.569 \\
\hline 2007 & 0.647 & 0.692 & 0.683 & 0.624 & 0.675 & 0.575 & 0.646 & 0.667 & 0.658 & 0.591 & 0.564 \\
\hline 2008 & 0.654 & 0.693 & 0.684 & 0.627 & 0.673 & 0.577 & 0.637 & 0.668 & 0.660 & 0.594 & 0.568 \\
\hline 2009 & 0.651 & 0.689 & 0.685 & 0.621 & 0.668 & 0.573 & 0.639 & 0.668 & 0.660 & 0.581 & 0.565 \\
\hline 2010 & 0.650 & 0.687 & 0.676 & 0.617 & 0.661 & 0.575 & 0.642 & 0.667 & 0.667 & 0.580 & 0.563 \\
\hline 2011 & 0.649 & 0.688 & 0.668 & 0.616 & 0.654 & 0.576 & 0.646 & 0.662 & 0.674 & 0.580 & 0.561 \\
\hline 2012 & 0.642 & 0.682 & 0.660 & 0.606 & 0.650 & 0.569 & 0.649 & 0.652 & 0.677 & 0.578 & 0.552 \\
\hline 2013 & 0.641 & 0.681 & 0.652 & 0.606 & 0.651 & 0.566 & 0.649 & 0.651 & 0.681 & 0.576 & 0.549 \\
\hline 2014 & 0.640 & 0.679 & 0.650 & 0.607 & 0.656 & 0.573 & 0.656 & 0.650 & 0.683 & 0.577 & 0.549 \\
\hline 2015 & 0.634 & 0.671 & 0.639 & 0.602 & 0.658 & 0.567 & 0.651 & 0.642 & 0.679 & 0.572 & 0.541 \\
\hline
\end{tabular}


Material Capacities Index for Semi-core states, 1975-2015

$\mathrm{MCl}$ Czech Rep. Finland Greece Hungary Ireland Luxemb. N. Zealand Portugal Singapore Slovakia Slovenia

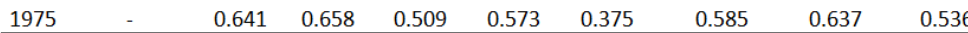

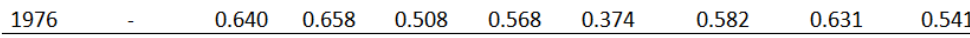

\begin{tabular}{llllllllll}
$1977 \quad-$ & 0.637 & 0.656 & 0.509 & 0.572 & 0.370 & 0.577 & 0.626 & 0.538 \\
\hline
\end{tabular}

\begin{tabular}{llllllllll}
1978 & - & 0.637 & 0.657 & 0.507 & 0.578 & 0.371 & 0.576 & 0.619 & 0.534 \\
\hline
\end{tabular}

\begin{tabular}{llllllllll}
1979 & - & 0.640 & 0.662 & 0.520 & 0.577 & 0.374 & 0.573 & 0.623 & 0.534 \\
\hline
\end{tabular}

\begin{tabular}{llllllllll}
\hline 1980 & - & 0.651 & 0.666 & 0.529 & 0.586 & 0.384 & 0.575 & 0.633 & 0.547
\end{tabular}

$\begin{array}{llllllllll}1981 & - & 0.647 & 0.660 & 0.550 & 0.583 & 0.377 & 0.583 & 0.627 & 0.558\end{array}$

\begin{tabular}{llllllllll}
\hline 1982 & - & 0.646 & 0.655 & 0.560 & 0.582 & 0.380 & 0.580 & 0.624 & 0.564
\end{tabular}

$\begin{array}{llllllllll}1983 & - & 0.638 & 0.643 & 0.583 & 0.574 & 0.400 & 0.577 & 0.611 & 0.566\end{array}$

\begin{tabular}{llllllllll}
1984 & - & 0.641 & 0.638 & 0.579 & 0.570 & 0.414 & 0.579 & 0.600 & 0.574 \\
\hline
\end{tabular}

$\begin{array}{llllllllll}1985 & - & 0.645 & 0.634 & 0.580 & 0.572 & 0.416 & 0.578 & 0.600 & 0.575\end{array}$

\begin{tabular}{llllllllll}
1986 & - & 0.646 & 0.638 & 0.585 & 0.579 & 0.419 & 0.591 & 0.612 & 0.570 \\
\hline
\end{tabular}

$\begin{array}{llllllllll}1987 & - & 0.667 & 0.647 & 0.586 & 0.592 & 0.407 & 0.602 & 0.630 & 0.575\end{array}$

\begin{tabular}{llllllllll}
1988 & - & 0.673 & 0.652 & 0.585 & 0.598 & 0.410 & 0.604 & 0.637 & 0.581 \\
\hline
\end{tabular}

$\begin{array}{llllllllll}1989 & - & 0.676 & 0.637 & 0.571 & 0.588 & 0.407 & 0.597 & 0.628 & 0.576\end{array}$

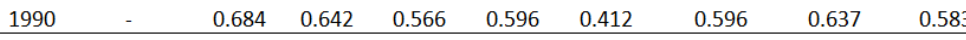

$\begin{array}{llllllllll}1991 & - & 0.678 & 0.650 & 0.565 & 0.596 & 0.419 & 0.585 & 0.646 & 0.594\end{array}$

$\begin{array}{llllllllll}1992- & - & 0.669 & 0.650 & 0.571 & 0.596 & 0.421 & 0.583 & 0.654 & 0.601\end{array}$

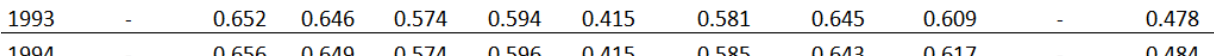

\begin{tabular}{|c|c|}
\hline 199 & 0.656 \\
\hline
\end{tabular}

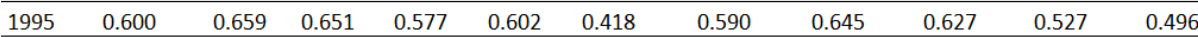

$\begin{array}{llllllllllll}1996 & 0.600 & 0.656 & 0.652 & 0.569 & 0.604 & 0.416 & 0.594 & 0.643 & 0.634 & 0.531 & 0.497\end{array}$

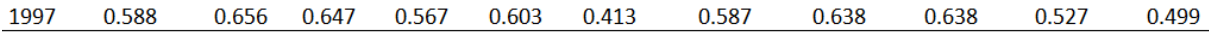

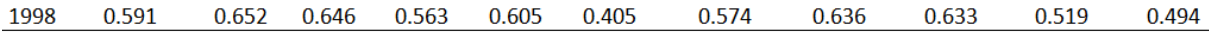

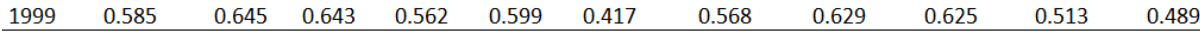

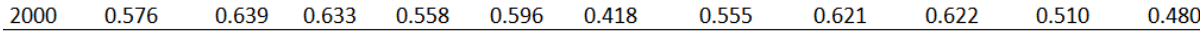

$\begin{array}{llllllllllll}2001 & 0.578 & 0.633 & 0.621 & 0.560 & 0.594 & 0.425 & 0.550 & 0.617 & 0.614 & 0.510 & 0.480\end{array}$

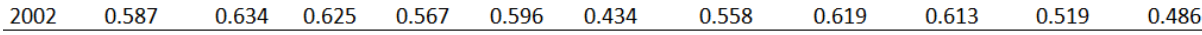

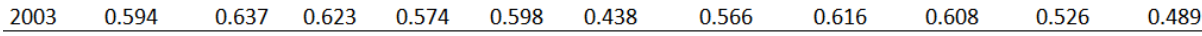

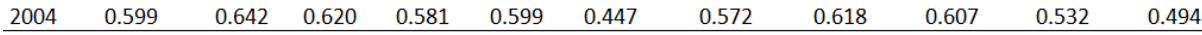

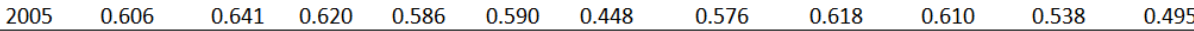

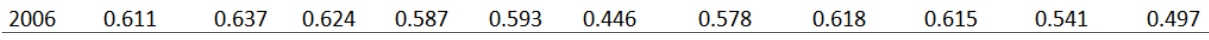

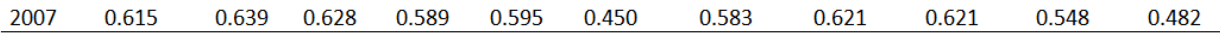

$\begin{array}{llllllllllll}2008 & 0.623 & 0.642 & 0.631 & 0.596 & 0.596 & 0.457 & 0.572 & 0.624 & 0.626 & 0.552 & 0.487\end{array}$

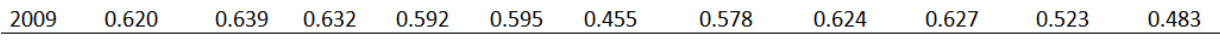

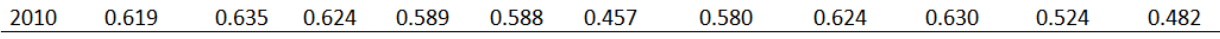

$\begin{array}{llllllllllll}2011 & 0.615 & 0.633 & 0.616 & 0.585 & 0.578 & 0.456 & 0.580 & 0.617 & 0.636 & 0.525 & 0.477\end{array}$

\begin{tabular}{|c|c|c|c|c|}
\hline 2012 & 0.610 & 0.627 & 0.60 & \\
\hline
\end{tabular}

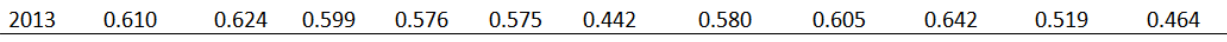

\begin{tabular}{|c|c|c|c|}
\hline 201 & 0.608 & 0.624 & 0.55 \\
\hline
\end{tabular}

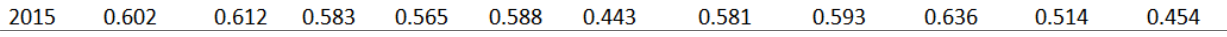


Semi-Material Capacities Index for Semi-core states, 1975-2015

SMCI Czech Rep. Finland Greece Hungary Ireland Luxemb. N. Zealand Portugal Singapore Slovakia Slovenia

\begin{tabular}{|c|c|c|c|c|c|c|c|c|c|c|c|}
\hline 1975 & - & 0.729 & 0.639 & 0.533 & 0.628 & 0.712 & 0.686 & 0.596 & 0.579 & - & - \\
\hline 1976 & - & 0.729 & 0.638 & 0.526 & 0.616 & 0.713 & 0.676 & 0.589 & 0.579 & - & - \\
\hline 1977 & - & 0.727 & 0.639 & 0.533 & 0.627 & 0.711 & 0.677 & 0.589 & 0.579 & - & - \\
\hline 1978 & - & 0.727 & 0.649 & 0.540 & 0.643 & 0.717 & 0.686 & 0.585 & 0.584 & - & - \\
\hline 1979 & - & 0.737 & 0.662 & 0.554 & 0.658 & 0.724 & 0.689 & 0.593 & 0.596 & - & - \\
\hline 1980 & - & 0.741 & 0.663 & 0.561 & 0.662 & 0.728 & 0.689 & 0.601 & 0.604 & - & - \\
\hline 1981 & - & 0.742 & 0.657 & 0.562 & 0.662 & 0.725 & 0.694 & 0.598 & 0.614 & - & - \\
\hline 1982 & - & 0.746 & 0.656 & 0.564 & 0.658 & 0.728 & 0.695 & 0.597 & 0.627 & - & - \\
\hline 1983 & - & 0.749 & 0.653 & 0.564 & 0.655 & 0.726 & 0.697 & 0.590 & 0.643 & - & - \\
\hline 1984 & - & 0.752 & 0.654 & 0.561 & 0.655 & 0.718 & 0.694 & 0.579 & 0.659 & - & - \\
\hline 1985 & - & 0.751 & 0.645 & 0.549 & 0.650 & 0.712 & 0.685 & 0.572 & 0.654 & - & - \\
\hline 1986 & - & 0.760 & 0.644 & 0.552 & 0.658 & 0.730 & 0.694 & 0.587 & 0.650 & - & - \\
\hline 1987 & - & 0.769 & 0.644 & 0.557 & 0.669 & 0.739 & 0.705 & 0.605 & 0.648 & - & - \\
\hline 1988 & - & 0.766 & 0.646 & 0.544 & 0.662 & 0.721 & 0.695 & 0.613 & 0.631 & - & - \\
\hline 1989 & - & 0.775 & 0.654 & 0.547 & 0.667 & 0.727 & 0.702 & 0.624 & 0.641 & - & - \\
\hline 1990 & - & 0.781 & 0.664 & 0.552 & 0.680 & 0.732 & 0.700 & 0.640 & 0.653 & - & - \\
\hline 1991 & - & 0.775 & 0.671 & 0.545 & 0.682 & 0.741 & 0.688 & 0.654 & 0.666 & - & - \\
\hline 1992 & - & 0.766 & 0.679 & 0.556 & 0.690 & 0.746 & 0.684 & 0.670 & 0.675 & - & 0.592 \\
\hline 1993 & - & 0.747 & 0.677 & 0.566 & 0.688 & 0.745 & 0.685 & 0.669 & 0.688 & - & 0.591 \\
\hline 1994 & - & 0.746 & 0.680 & 0.574 & 0.694 & 0.749 & 0.693 & 0.671 & 0.702 & - & 0.601 \\
\hline 1995 & 0.610 & 0.754 & 0.686 & 0.573 & 0.700 & 0.759 & 0.704 & 0.677 & 0.711 & 0.561 & 0.619 \\
\hline 1996 & 0.621 & 0.762 & 0.692 & 0.572 & 0.710 & 0.761 & 0.711 & 0.684 & 0.719 & 0.577 & 0.630 \\
\hline 1997 & 0.613 & 0.767 & 0.696 & 0.573 & 0.719 & 0.761 & 0.712 & 0.686 & 0.729 & 0.581 & 0.637 \\
\hline 1998 & 0.612 & 0.760 & 0.689 & 0.570 & 0.717 & 0.750 & 0.698 & 0.682 & 0.716 & 0.576 & 0.632 \\
\hline 1999 & 0.613 & 0.762 & 0.691 & 0.578 & 0.727 & 0.753 & 0.699 & 0.687 & 0.717 & 0.582 & 0.639 \\
\hline 2000 & 0.608 & 0.757 & 0.687 & 0.579 & 0.730 & 0.749 & 0.689 & 0.685 & 0.716 & 0.583 & 0.635 \\
\hline 2001 & 0.615 & 0.753 & 0.686 & 0.583 & 0.727 & 0.744 & 0.685 & 0.680 & 0.705 & 0.586 & 0.632 \\
\hline 2002 & 0.611 & 0.748 & 0.683 & 0.589 & 0.726 & 0.736 & 0.684 & 0.675 & 0.699 & 0.586 & 0.628 \\
\hline 2003 & 0.625 & 0.755 & 0.695 & 0.608 & 0.739 & 0.736 & 0.696 & 0.682 & 0.698 & 0.596 & 0.637 \\
\hline 2004 & 0.640 & 0.767 & 0.710 & 0.624 & 0.753 & 0.756 & 0.712 & 0.693 & 0.701 & 0.613 & 0.650 \\
\hline 2005 & 0.645 & 0.768 & 0.713 & 0.627 & 0.758 & 0.762 & 0.716 & 0.693 & 0.701 & 0.618 & 0.652 \\
\hline 2006 & 0.649 & 0.767 & 0.713 & 0.625 & 0.759 & 0.755 & 0.709 & 0.688 & 0.703 & 0.622 & 0.651 \\
\hline 2007 & 0.651 & 0.767 & 0.714 & 0.622 & 0.759 & 0.762 & 0.710 & 0.688 & 0.706 & 0.629 & 0.653 \\
\hline 2008 & 0.654 & 0.762 & 0.710 & 0.619 & 0.751 & 0.751 & 0.695 & 0.682 & 0.697 & 0.626 & 0.651 \\
\hline 2009 & 0.650 & 0.756 & 0.709 & 0.612 & 0.738 & 0.737 & 0.697 & 0.681 & 0.698 & 0.622 & 0.645 \\
\hline 2010 & 0.651 & 0.756 & 0.700 & 0.608 & 0.729 & 0.742 & 0.699 & 0.679 & 0.706 & 0.622 & 0.643 \\
\hline 2011 & 0.651 & 0.757 & 0.690 & 0.606 & 0.720 & 0.741 & 0.705 & 0.673 & 0.714 & 0.620 & 0.642 \\
\hline 2012 & 0.641 & 0.749 & 0.675 & 0.595 & 0.715 & 0.730 & 0.711 & 0.661 & 0.720 & 0.617 & 0.631 \\
\hline 2013 & 0.640 & 0.751 & 0.665 & 0.595 & 0.719 & 0.726 & 0.716 & 0.659 & 0.728 & 0.616 & 0.628 \\
\hline 2014 & 0.641 & 0.751 & 0.662 & 0.595 & 0.724 & 0.739 & 0.721 & 0.659 & 0.734 & 0.617 & 0.630 \\
\hline 2015 & 0.635 & 0.742 & 0.651 & 0.590 & 0.722 & 0.730 & 0.715 & 0.652 & 0.726 & 0.610 & 0.623 \\
\hline
\end{tabular}


Immaterial Capacities Index for Semi-core states, 1975-2015

IMCI Czech Rep. Finland Greece Hungary Ireland Luxemb. N. Zealand Portugal Singapore Slovakia Slovenia

$\begin{array}{llllllllll}1975 & - & 0.666 & 0.658 & 0.618 & 0.616 & 0.489 & 0.656 & 0.620 & 0.501\end{array}$

\begin{tabular}{llllllllll}
\hline 1976 & - & 0.665 & 0.654 & 0.615 & 0.607 & 0.484 & 0.648 & 0.611 & 0.492
\end{tabular}

\begin{tabular}{llllllllll}
\hline 1977 & - & 0.668 & 0.663 & 0.619 & 0.613 & 0.493 & 0.657 & 0.615 & 0.504 \\
\hline
\end{tabular}

\begin{tabular}{llllllllll}
\hline 1978 & - & 0.666 & 0.667 & 0.623 & 0.621 & 0.497 & 0.663 & 0.614 & 0.521 \\
\hline
\end{tabular}

$\begin{array}{llllllllll}1979 & - & 0.671 & 0.674 & 0.626 & 0.630 & 0.501 & 0.664 & 0.615 & 0.527\end{array}$

\begin{tabular}{llllllllll}
\hline 1980 & - & 0.674 & 0.673 & 0.624 & 0.638 & 0.502 & 0.663 & 0.626 & 0.515
\end{tabular}

\begin{tabular}{llllllllll}
\hline 1981 & - & 0.670 & 0.669 & 0.620 & 0.632 & 0.491 & 0.659 & 0.621 & 0.510
\end{tabular}

$\begin{array}{llllllllll}1982 & - & 0.668 & 0.669 & 0.618 & 0.631 & 0.483 & 0.656 & 0.617 & 0.523\end{array}$

$\begin{array}{llllllllll}1983 & - & 0.666 & 0.665 & 0.613 & 0.628 & 0.479 & 0.653 & 0.612 & 0.535\end{array}$

\begin{tabular}{llllllllll}
\hline 1984 & - & 0.663 & 0.661 & 0.605 & 0.621 & 0.472 & 0.641 & 0.604 & 0.516
\end{tabular}

\begin{tabular}{llllllllll}
\hline 1985 & - & 0.669 & 0.668 & 0.602 & 0.619 & 0.473 & 0.644 & 0.611 & 0.545 \\
\hline
\end{tabular}

\begin{tabular}{lllllllllll}
\hline 1986 & - & 0.679 & 0.671 & 0.607 & 0.631 & 0.483 & 0.652 & 0.628 & 0.537
\end{tabular}

$\begin{array}{llllllllll}1987 & - & 0.686 & 0.676 & 0.605 & 0.632 & 0.492 & 0.659 & 0.634 & 0.550\end{array}$

\begin{tabular}{llllllllll}
1988 & - & 0.688 & 0.673 & 0.610 & 0.629 & 0.487 & 0.661 & 0.640 & 0.545 \\
\hline
\end{tabular}

\begin{tabular}{llllllllll}
\hline 1989 & - & 0.689 & 0.677 & 0.627 & 0.626 & 0.491 & 0.657 & 0.646 & 0.561 \\
\hline
\end{tabular}

\begin{tabular}{llllllllll}
\hline 1990 & - & 0.698 & 0.682 & 0.638 & 0.632 & 0.502 & 0.654 & 0.658 & 0.576
\end{tabular}

\begin{tabular}{|c|c|c|c|c|c|c|c|c|}
\hline 1991 & - & 0.697 & 0.682 & 0.644 & 0.633 & 0.501 & 0.650 & 0.668 \\
\hline
\end{tabular}

\begin{tabular}{llllllllll}
\hline 1992 & - & 0.690 & 0.683 & 0.648 & 0.637 & 0.510 & 0.646 & 0.676 & 0.567 \\
\hline
\end{tabular}

$1993 \quad-\quad$\begin{tabular}{llllllllllllll} 
& 0.678 & 0.683 & 0.654 & 0.635 & 0.511 & 0.649 & 0.674 & 0.578 & - & 0.516 \\
\hline
\end{tabular}

\begin{tabular}{lllllllllllll}
\hline 1994 & - & 0.679 & 0.683 & 0.651 & 0.638 & 0.522 & 0.648 & 0.679 & 0.599 & - & 0.512 \\
\hline 1995 & 0.658 & 0.693 & 0.696 & 0.648 & 0.645 & 0.532 & 0.654 & 0.688 & 0.614 & 0.588 & 0.515
\end{tabular}

\begin{tabular}{llllllllllll}
1996 & 0.661 & 0.688 & 0.691 & 0.645 & 0.643 & 0.524 & 0.654 & 0.686 & 0.646 & 0.591 & 0.505 \\
\hline
\end{tabular}

\begin{tabular}{llllllllllll}
\hline 1997 & 0.658 & 0.683 & 0.691 & 0.645 & 0.646 & 0.523 & 0.651 & 0.683 & 0.645 & 0.584 & 0.502 \\
\hline
\end{tabular}

\begin{tabular}{llllllllllll}
1998 & 0.659 & 0.683 & 0.696 & 0.646 & 0.648 & 0.521 & 0.641 & 0.688 & 0.640 & 0.587 & 0.516 \\
\hline
\end{tabular}

\begin{tabular}{llllllllllll}
1999 & 0.653 & 0.677 & 0.692 & 0.641 & 0.644 & 0.517 & 0.639 & 0.685 & 0.636 & 0.577 & 0.513 \\
\hline
\end{tabular}

\begin{tabular}{llllllllllll}
2000 & 0.651 & 0.671 & 0.699 & 0.640 & 0.648 & 0.517 & 0.632 & 0.686 & 0.652 & 0.577 & 0.511 \\
\hline & 0.654 & 0.670 & 0.698 & 0.643 & 0.653 & 0.519 & 0.630 & 0.686 & 0.650 & 0.580 & 0.531
\end{tabular}

$\begin{array}{llllllllllll}2002 & 0.662 & 0.672 & 0.704 & 0.651 & 0.659 & 0.526 & 0.638 & 0.688 & 0.648 & 0.582 & 0.546\end{array}$

\begin{tabular}{llllllllllll}
2003 & 0.676 & 0.683 & 0.714 & 0.665 & 0.673 & 0.541 & 0.655 & 0.700 & 0.649 & 0.597 & 0.577 \\
\hline
\end{tabular}

\begin{tabular}{llllllllllll}
\hline 2004 & 0.677 & 0.684 & 0.719 & 0.665 & 0.678 & 0.550 & 0.659 & 0.703 & 0.650 & 0.597 & 0.580 \\
\hline
\end{tabular}

\begin{tabular}{llllllllllll}
\hline 2005 & 0.681 & 0.686 & 0.721 & 0.670 & 0.685 & 0.551 & 0.664 & 0.706 & 0.654 & 0.601 & 0.583 \\
\hline
\end{tabular}

\begin{tabular}{llllllllllll}
\hline 2006 & 0.683 & 0.684 & 0.720 & 0.667 & 0.687 & 0.551 & 0.659 & 0.705 & 0.658 & 0.605 & 0.582 \\
\hline
\end{tabular}

\begin{tabular}{llllllllllll}
\hline 2007 & 0.686 & 0.688 & 0.725 & 0.671 & 0.695 & 0.556 & 0.667 & 0.709 & 0.661 & 0.610 & 0.586 \\
\hline
\end{tabular}

\begin{tabular}{llllllllllll}
\hline 2008 & 0.695 & 0.692 & 0.728 & 0.676 & 0.698 & 0.561 & 0.665 & 0.711 & 0.667 & 0.619 & 0.593 \\
\hline
\end{tabular}

\begin{tabular}{llllllllllll}
\hline 2009 & 0.693 & 0.689 & 0.731 & 0.668 & 0.694 & 0.565 & 0.661 & 0.713 & 0.666 & 0.617 & 0.594 \\
\hline
\end{tabular}

\begin{tabular}{lllllllllll}
\hline 2010 & 0.691 & 0.688 & 0.720 & 0.665 & 0.689 & 0.565 & 0.669 & 0.711 & 0.679 & 0.614 \\
\hline
\end{tabular}

\begin{tabular}{llllllllllll}
\hline 2011 & 0.692 & 0.691 & 0.716 & 0.666 & 0.690 & 0.571 & 0.674 & 0.710 & 0.684 & 0.614 & 0.592 \\
\hline
\end{tabular}

\begin{tabular}{llllllllllll}
\hline 2012 & 0.685 & 0.688 & 0.716 & 0.658 & 0.686 & 0.568 & 0.675 & 0.702 & 0.685 & 0.611 & 0.587 \\
\hline
\end{tabular}

\begin{tabular}{llllllllllll}
2013 & 0.684 & 0.687 & 0.709 & 0.657 & 0.685 & 0.571 & 0.674 & 0.703 & 0.687 & 0.611 & 0.584 \\
\hline
\end{tabular}

\begin{tabular}{lllllllllllll}
2013 & 0.684 & 0.687 & 0.709 & 0.657 & 0.685 & 0.571 & 0.674 & 0.703 & 0.687 & 0.611 & 0.584 \\
\hline 2014 & 0.682 & 0.683 & 0.711 & 0.661 & 0.689 & 0.575 & 0.680 & 0.704 & 0.687 & 0.615 \\
\hline 2015 & 0.675 & 0.677 & 0.703 & 0.662 & 0.687 & 0.571 & 0.680 & 0.695 & 0.689 & 0.611 & 0.577 \\
\hline
\end{tabular}




\section{REFERENCES}

Acemoglu, Daron, and James Robinson. Por qué fracasan los países. México: Crítica, 2012.

Aguirre Rojas, Carlos Antonio. Immanuel Wallerstein: crítica del sistema-mundo capitalista. México, D.F.: Ediciones Era, 2003.

Barre, Raymond. El desarrollo económico. México, D. F.: Fondo de Cultura Económica, 1962.

Braudel, Fernand. La dinámica del capitalismo. México, D. F.: Fondo de Cultura Económica, I986.

Cardoso, Fernando Henrique, and Enzo Faletto. Dependencia y desarrollo en América Latina. México, D. F.: Siglo XXI, I999.

Castells, Manuel. La era de la información: economía, sociedad y cultura. Vol. I: La sociedad red. México, D. F.: Siglo XXI Editores, 2005a.

Dauvergne, Peter. «Globalization and the environment.» En Global political economy, de John Ravenhill, 450-480. Nueva York: Oxford University Press, 20II.

Drucker, Peter. La sociedad postcapitalista. Bogotá: Grupo Editorial Norma, I994.

Estay, Jaime. «Raúl Prebisch.» Ensayos de Economía (Universidad Nacional de Colombia), I995: I23-I32.

Gudynas, Eduardo. Ecología, economía y ética del desarrollo sostenible. Montevideo: Coscoroba Ediciones, 2004 .

International Monetary Fund. World economic outlook. abril de 2013. http:// www.imf.org/external/pubs/ft/weo/2013/or/pdf/text.pdf (último acceso: septiembre de 20I3).

Kennedy, Paul. Auge y caida de las grandes potencias. México, D. F.: DeBols!llo, 2007.

Lianos, Theodore P. «Concentration and centralization of capital in agriculture.» Studies in Political Economy I4 (I984): 99-II6.

Love, Joseph L. «Las fuentes del estructuralismo latinoamericano.» Desarrollo Económico. Revista de Ciencias Sociales (Instituto de Desarrollo Económico y Social) 36, nffl I4I (abril-junio I996): 39I-402.

Marini, Ruy Mauro. Dialéctica de la dependencia. México, D. F.: Era, I986.

Marx, Karl. El capital. Tomo I. México, D. F.: Fondo de Cultura Económica, I999.

Nye, Joseph. Power in a global information age. Nueva York: Routledge, 2004 b. 
—. Soft power. The means to success in World Politics. Nueva York: PublicAffairs, 2004a.

Pirenne, Henri. Historia económica y social de la Edad Media. México, D. F.: Fondo de Cultura Económica, 2003.

Prebisch, Raúl. «Crítica al capitalismo periférico.» Revista de la CEPAL (Comisión Económica para América Latina), nffl I (Primer semestre I976): 7-73.

Rocha, Alberto, and Daniel Morales. "El poder nacional-internacional de los Estados. Una propuesta trans-estructural." Geopolítica(s) (Universidad Complutense de Madrid) 9, no. I (2018): I37-169.

Rocha, Alberto, and Daniel Morales. "Potencias medias y potencias regionales en el Sistema Político Internacional.” Geopolítica(s) I, no. 2 (2010): 25I-279.

Singer, Paul. Curso de introducción a la economía política. México, D. F.: Siglo XXI Editores, I999.

Sombart, Werner. El apogeo del capitalismo. Tomo I. México, D. F.: Fondo de Cultura Económica, I946.

Spivak, Gayatri Chakravorty. Crítica de razón poscolonial: hacia una historia del presente evanescente. Madrid: Akal, 20 оо.

Sunkel, Osvaldo, and Pedro Paz. El subdesarrollo latinoamericano y la teoría del desarrollo. México, D. F.: Siglo XXI Editores, I980.

Taylor, Peter J., and Colin Flint. Geografía política. Madrid: Trama Editorial, 2002.

Valdés, Pablo, and Juan Salazar. Manual de política mundial contemporánea. Santiago de Chile: Editorial Andrés Bello, I987.

Wallerstein, Immanuel. El moderno sistema mundial. Tomo I: la agricultura capitalista y los orígenes de la economía-mundo europea en el siglo XVI. México, D.F.: Siglo XXI, 2003.

-. Geopolítica y geocultura. Barcelona: Kairós, 2007.

Wallerstein, Immanuel. «The inter-state structure of the modern world-system.» En International theory: positivism and beyond, de Steve Smith, Ken Booth y Marysia Zalewski, 87-I07. Nueva York: Cambridge University Press, 2008.

World Tourism Organization. «Manila Declaration on World Tourism.» UNWTO eLibrary. Io de octubre de I980. https://www.e-unwto.org/doi/ pdf/ıo.I8ıı/unwtodeclarations.ı980.6.4.I (último acceso: April de 20I8). 
Zapata, Francisco. Ideología y política en América Latina. México, D. F.: El Colegio de México, 200I.

\begin{abstract}
Do all the core states occupy identical positions in the hierarchy of world power and perform the same functions? The hypothesis outlined here is that there is an unforeseen category: semi-core states. They have very important socio-institutional power but are "tertiary" in terms of economic-military and communicative-cultural power. Despite their relative marginality, they play strategic roles in international politics, especially in support of the central powers (great and middle). This article analyzes the general characteristics of the so-called center of the world-system, identifies the semi-core states theoretically and empirically, explores their genesis and analyzes their roles in the international system.
\end{abstract}

\title{
KEYWORDS
}

Semi-core states, great powers, middle powers, international structure, world-system, World Power Index. 